1 Ress P.UN millenium health goals will not be achieved, report warns. $B M J$ 2005;331:474.

2 National Statistical Office, Malawi. Malawi Demographic and Health Survey, 2000. www.nso.malawi.net/data_on_line/demography/dhs/main_report Contents.pdf (accessed 24 Sep $200 \overline{5}$ ).

3 UN Millenium Project, Task Force Child Health and Maternal Health. Who's got the power? transforming health systems for women and children: achieving the millenium development goals. 2005. www. unmillenniumproject.org/reports/tf_health.htm (accessed 24 Sep 2005).

4 Liljestrand J, Gryboski K. Women who die needlessly: maternal mortality as a human rights issue. In: Murphy E, Hendrix-Jenkins A, eds. Reproductive health and rights-reaching the hardly reached. PATH, 2002. www.path.org/publications/pub.php?id $=515$ (accessed 24 Sep 2002.

5 Mirsky J. Call for a human rights approach to tackle high levels of maternal death and disability. Panos Institute/Medianet, 2001. www.eldis.org/static/ DOC15124.htm (accessed 24 Sep 2005).

6 Barnett B, Stein J. Women's voices, women's lives: the impact of family planning. Family Health International, 1998. www.fhi.org/en/RH/Pubs/wsp/ synthesis/index.htm (accessed 24 Sep 2005).
7 Lule E, Ramana GNV, Ooman N, Epp J, Huntington D, Rosen JF Achioring the millennium development goal of improving maternal health: determinants the millenian development goal of improving maternal health: determinans, meronions and chellonger. New York: World Bank, 2005. hip:// Resources/281627-1095698140167/LuleAchievingtheMDGFinal.pdf (accessed 24 Sep 2005)

8 Prevention of Maternal Mortality Network. Barriers to treatment of obstetric emergencies in rural communities of West Africa. Stud Family Plan 1992;23:279-91

9 Standing, H. Towards reproductive health for all? Reflections on international development commitments. In: Black R, White H, eds. Targeting development:critical perspectives on the millennium development goals. London: Routledge, 2003.

10 Center for Health and Gender Equity. Rep Chris Smith guts program to save women's lives. Press release 25 July 2005: www.genderhealth.org/ pubs/PR20050720.pdf (accessed 31 Aug 2005)

11 Goodburn E, Campbell O. Reducing maternal mortality in the developing world: sector-wide approaches may be the key. BMJ 2001;322:917.

122 Millennium Project Task Force. Interim report on gender equality 2004. www.unmillenniumproject.org/documents/tf3genderinterim.pdf (accessed 24 Sep 2005).

\title{
Medicines supply in Africa
}

\section{Should improve through regional collaborations and accredited drug shops}

$\mathrm{L}$ ack of access to medicines each year contributes to millions of deaths and untold suffering in all treatable with existing medicines-kill an estimated 6 million people every year, mostly in sub-Saharan Africa. ${ }^{1}$ The burden falls mainly on the poor, women, and especially children. ${ }^{2}$

Over the past three decades, African governments have worked to provide medicines to populations with growing health needs. During that period the World Health Organization has advocated increasing access to medicines ${ }^{3-5}$; the World Bank has pushed for reforms in the health sector; and Unicef has launched the 1987 Bamako Initiative, meant to improve communities' access to pharmaceuticals. Despite these efforts, WHO estimates that roughly 270 million people in Africanearly half the population-lack regular access to even the most essential medicines. ${ }^{6}$

Poverty, diverse geography, and social upheaval all contribute to the problem of access. The public sector's supply systems are plagued by inadequate financing, weak management systems, lack of accountability, and a devastating reduction in the healthcare workforce. ${ }^{7}$ The formal private sector is generally limited to urban areas. Faith based and other non-governmental services supplying health care are often well run, but typically handle less than $15 \%$ of a country's pharmaceutical market.

In this context, tinkering with existing models of supply is unlikely to close the huge gap in access to medicines. Policy makers, health officials, and others concerned with improving health in Africa must find new solutions. These may include overhauls of policy, financing, and frameworks for regulation; a realignment of responsibilities between public and private sectors; and the forging of genuine public-private relationships to help in implementing the supply of medicines.

The first source of medicines in much of Africa is the corner kiosk or other informal drug seller. Though these sources are easily accessible, customers often receive inappropriate medicines of poor quality. for over $60 \%$ of the population-has developed a system of accredited "duka la dawa muhimu" (essential drugs shops). Staff are trained in dispensing and business skills, and shops are now regularly inspected and reliably supplied with registered medicines. Dispensing recommendations and the availability and quality of products have improved more in the accredited shops than in informal shops. ${ }^{9}$ Innovative public-private franchising and accreditation have also been introduced successfully in Ghana and Kenya and are being developed in Nigeria and elsewhere. Considerable effort is needed if such schemes are to maintain dispensing practices that contribute to health improvements, provide access to the poorest of the poor, and ensure financial and managerial sustainability.

African countries need to develop integrated systems for the supply chain that fully use the capacity of the public, non-governmental, and commercial sectors. One approach is the primary distributor model, ${ }^{10}$ whereby the government contracts that private companies will operate the pharmaceutical supply chain, while it provides contractual oversight and controls the procurement process. Another approach allows private or non-governmental systems to supply a particular area or specific health facilities. Such innovative public-private relationships have been implemented on a small scale in several African countries, including Zambia, South Africa, Tanzania, Kenya, and Uganda. However, such efforts fail to improve the supply of medicines if the private sector is weak, lacks independent management, or is insufficiently accountable.

Africa's regions could use economies of scale to buy medicines and assure their quality. Similar needs for medicines, shared sources of supply, and lack of national expertise in procurement all argue for greater collaboration among neighbouring countries. Regional partnerships might include sharing information on pricing and suppliers, establishing formal group purchasing schemes, and contracting with commercial distributors to supply health programmes throughout the region. The Southern Africa Development Community, the West Africa 
Health Organization, and the East, Central, and Southern Africa Health Community are actively exploring such collaboration. Experience from the eastern Caribbean and the Gulf States has already shown the potential savings and sustainability of such arrangements. ${ }^{11}$

The current systems for pharmaceutical supply in many parts of Africa are overwhelmed. Policy makers and healthcare managers must fundamentally change their thinking. The real challenge is to identify, select, and implement the best solutions for each country's situation. As the conference in June on strategies for enhancing access to medicines concluded, "Africa is learning in its own way how its own forms of private and public enterprise can work together in the particular way that Africa needs."12

Jonathan D Quick president and chief executive officer (jquick@msh.org)

Nana-Adjoa Boohene senior programme associate Management Sciences for Health, 784 Memorial Drive, Cambridge, MA 02139, USA

James Rankin director, Center for Pharmaceutical Management

Management Sciences for Health, 4301 N Fairfax Drive, Suite 400, Arlington, VA 22203, USA

Romuald J Mbwasi senior technical adviser

Management Sciences for Health, ASG Building Nyerere Road, PO Box 50104, Dar es Salaam, Tanzania
We are grateful for the assistance of Martha Embrey, David Lee, and Keith Johnson in the preparation of this editorial.

Competing interests: None declared.

1 Global Fund for HIV/AIDS, Tuberculosis and Malaria. HIV/AIDS, tuberculosis and malaria: the status and impact of the three diseases. Geneva: Global Fund, 2005

2 Black RE, Morris SS, Bryce J. Where and why are 10 million children dying every year? Lancet 2003;361:2226-34.

3 Quick JD. Essential medicines twenty-five years on: closing the access gap. Health Policy Plan 2003; 18:1-3.

4 World Health Organization. WHO medicines strategy: countries at the core 2004-2007. http://whqlibdoc.who.int/hq/2004/WHO_EDM_2004.5.pdf (accessed 26 Sep 2005).

5 UN Millennium Project. Prescription for healthy development: increasing access to medicines. Sterling, VA: Earthscan, 2005. (Report of the Task Force on HIV/AIDS, Malaria, TB, and Access to Essential Medicines, Working Group on Access to Essential Medicines.)

6 WHO. The world medicines situation. Geneva: World Health Organization, 2004. www.eldis.org/static/DOC17161.htm (accessed 22 Sep 2005).

7 Chen L, Evans T, Anand S, Boufford JI, Brown H, Chowdhury M, et al. Human resources for health: overcoming the crisis. Lancet 2004; 364:1984-90.

8 Kawasaki E, Patten JP. Drug supply systems of missionary organizations identifying factors affecting expansion and efficiency: case studies from Uganda and Kenya. Prepared for WHO/EDM. 2002. (World Health Organization \#HQ/01191467.)

9 Mbwasi R. Using a holistic approach to transform private sector drug outlets: the Tanzania experience. Presented at the Strategies for Enhancing Access to Medicines Conference, Accra, Ghana 20-22 June 2005. www.msh.org/seam/conference2005 (accessed 22 Sep 2005).

10 Management Sciences for Health. Drug supply strategies. In: Managing drug supply. 2nd ed. Bloomfield, CT: Kumarian Press, 1997.

11 Center for Pharmaceutical Management. Regional pooled procurement of drugs in sub-Saharan Africa.. Arlington, VA: Management Sciences for Health, 2002. (Produced for Rockefeller Foundation.)

12 Dukes, G. Moving forward-now! Presented at the Strategies for Enhancing Access to Medicines Conference, Accra, Ghana, 20-22 June 2005. www.msh.org/seam/conference2005 (accessed 22 Sep 2005).

\section{Road safety in Africa}

\section{Is part of the broader development process}

We must now use every day to act on road safety, and implement effective sustainable action to prevent injury and death on the world's roads.

Dr Lee Jong-wook, director-general, World Health Organization

$\mathrm{T}$ The World Report on Road Traffic Injury Prevention notes that political will and commitment are important for sustainable prevention of road traffic injuries. ${ }^{1}$ Development agencies need to place road safety in Africa and elsewhere at the centre of the global agenda along with the institutional, political, economic, and social issues which make roads so dangerous. For example, the World Summit on Sustainable Development held in Johannesburg, South Africa, in September 2002 did not include a single item on road safety-a growing problem in Africa and other low income and middle income countries-on its agenda, declaration, or plan of action. ${ }^{2}$

Africa's economic and social conditions began to deteriorate in the 1970 s and have continued to do so. ${ }^{34}$ Between 1990 and 2002, the gross national income per capita grew at an annual average of $0.5 \%$ for all Africa and $0.02 \%$ for sub-Saharan Africa. ${ }^{5}$ Africa is faced with declining agricultural output, foreign debt burden, unemployment, poorly performing industry, deteriorating healthcare systems, HIV/AIDS, environmental insecurity, and political instability. ${ }^{6}$ This is the context in which the problem of road safety has to be addressed. Several issues require reflection and action. How does the prevailing economic situation in Africa affect the amount of resources devoted to road safety? In what ways does the political setting that has been characterised by instability in many countries affect development of institutions and capacity for road safety and other sectors? Bishai and colleagues show that budgetary expenditure on road safety at all levels of government in Uganda is US $\$ 0.09$ per capita. ${ }^{7}$ This problem of low and negligible resource allocation to road safety in Africa needs to be addressed: at the moment, funding for road safety activities in Africa is very limited, a mere drop in the ocean.

Road transport can contribute to the socioeconomic development of Africa through facilitating movement of goods and people, opening up isolated areas, and promoting trade. ${ }^{8}$ Intricate movement patterns involve short, medium, and long distances, different modes of transport, and interaction within and between different places in Africa. ${ }^{8}$ The number of motor vehicles, volume of road traffic, and utilisation of the road by different road users in Africa have grown noticeably. The bicycle is increasingly used for passenger and freight transport in urban and rural areas. ${ }^{9}$ These transport characteristics indicate the need to pay adequate attention to safety measures in road transport development, especially safety of urban and 